\title{
Contrasting Patterns of Industrial Relations in Britain
}

\author{
Mick Marchington*
}

Given that Mrs Thatcher is no longer Prime Minister, now seems an appropriate time to try and provide an assessment of where industrial relations currently stands in Britain, and what has been the impact of Thatcherism on the system. This exercise has a certain intellectual as well as practical appeal given the grand claims which have been made about the extent of change in the UK since 1979. It is true to say that there has been considerable change to the national institutions and the legal framework for industrial relations in Great Britain. But, at the same time, there are also doubts as to whether this has been reflected in concrete industrial relations practices at the workplace. Interesting as this debate is however, it is argued here that it is misleading because a whole series of assumptions are made about the character of British industrial relations, both in 1979 and in 1991, which are not applicable across the economy as a whole. A much more useful approach is to focus on the variety which exists in British industrial relations, and to outline in a series of patterns of industrial relations rather than trying to describe a universal all embracing picture.

\section{The British context}

There are a number of factors which have provided a backcloth to the system of industrial relations in Britain over the course of the last decade. Here, we will focus on six of these. First, although there are differences between sectors, most analysts are agreed that employers have faced an increasingly competitive product market environment since the late 1970s. Some of this has been stimulated by the penetration of Japanese firms into Britain, but it has also been affected by deregulation and commercialisation within the public sector as well. The emphasis on customers and competitors is now much more explicit than it was a decade ago.

Second, there have been major shifts in the structure of employment since the 1970 s. The number of people employed in manufacturing and the public sector has declined considerably over this period, and now each of these counts for less than $25 \%$ of the workforce in the country. In contrast the private service sector now counts for $50 \%$ of all employment. Connected with these sectoral changes are also adjustments in the patterns of employment with a growth in the number of people employed on part-time and temporary contracts.

Third, the number of employees who are members of trade unions has declined since the late 1970 s when it reached a peak of over 13 million. This has now fallen to less than nine million and the density of unionisation has gone down to below $40 \%$ from a height of $55 \%$. In addition, the size of the non Trades Union Congress affiliate sector has also 
increased, partly due to the expulsion of the Electricians' Union, but also due to the growth of other employee organisations. There are also suggestions that the character of workplace trade union organisation has changed as well, especially within manufacturing as shop stewards and employees have learnt to cope with the changed economic circumstances in which their firms compete.

Fourth, three successive Conservative governments have developed a free market approach to the economy and have attempted to remove restrictions on employers in the labour market. This has been promoted alongside a spirit of enterprise and individualism, as well as support for employers who choose to adopt policies which suit their own contextual conditions. The legislation against trade unions has also intensified during the $1980 \mathrm{~s}$, and now the closed-shop is unlawful in Britain, as are many forms of industrial action and picketing. At the same time, the British Government is under pressure from the rest of the European Community to harmonise certain social aspects of work and employment across all of the member states.

The fifth contextual factor which has affected industrial relations in Britain over the decade is concerned with technological change. The introduction of new technology has been apparent in most industries, ranging from chemicals with increasingly computerised and automated equipment through to retail stores which now engage in EPOS, laser scanning, and computerised warehouse operations.

Finally, there have been changes to organisation structure and culture which have had an impact on the nature of industrial relations at work. There has been an increasing devolution in the structure of management decision making with a greater emphasis on profit centres and individual establishments. At the same time, there have been moves by some employers to introduce what are commonly referred to as "HRM practices" - such as performance appraisal, sophisticated selection procedures, performance related pay, and employee involvement techniques. This is probably best exemplified by the statement that "people are the company's most important resource".

\section{Change in industrial relations?}

We have already seen how the national framework within which industrial relations is conducted has changed significantly during the $1980 \mathrm{~s}$, but it cannot be assumed from this that there have also been changes to patterns of industrial relations at work. There has been considerable debate about this in Britain over the last few years. At one extreme is the view taken by Metcalf (1989) who argues that, amongst other things, people are working harder and labour productivity has increased faster during the 1980 s than in previous periods. He suggests (p.2) that "Thatcherism appears to have worked" and that industrial relations reform has played a sizeable part in improvements to the British economy. This evaluation has also found some support from other writers and some politicians; and a long list of changes/new initiatives have been catalogued as evidence of a "new industrial relations". For example, the following have been noted: functional and numerical flexibility, direct employee involvement and communications, performance-related pay, non-union workplaces, single union deals and single-table bargaining, and a spirit of "new realism" amongst trade union leaders and shop stewards.

At the other extreme is the view of people such as MacInnes (1987) and Pollert (1988) who have argued that there has been much less evidence of adjustment to the practice of 
industrial relations. In particular, they question the extent of change in the area of workforce flexibility, and an Advisory Conciliation and Arbitration Service (ACAS) survey of 1988 illustrated that many more workplaces had seen no change to work organisation than had been subject to adjustments. In between these views, there are a number of other authors who suggest there have been elements of both continuity and change in the structure of British industrial relations. For example, Batstone (1984), Millward and Stevens (1986), and Sisson (1986) have all argued that whilst the institutions of collective bargaining and consultation have for the most part remained intact, there have been other developments as well which have heralded new ideas and new initiatives; for example in the areas of employee involvement, as well as in the subject matter which is covered by collective bargaining.

What is interesting is why these different views have emerged, and it seems that at least three separate suggestions have been put forward in the literature. First, different authors may well have been focusing on different issues and this has led them to come up with alternative evaluations about the extent of change. So, for example, Metcalf has focused upon unions and productivity, whilst Pollert has concentrated on flexibility and MacInnes has looked at flexibility and employee involvement. Arguably, there may be more difference between the policy rhetoric when employers are talking about flexibility and employee involvement than if there are discussions about productivity. It is often easy for senior managers to assume that employee involvement is rather more widespread in the workplace than it actually is because of formal institutions which have been established at national level.

The second reason for differences in views could be that students have focused on different industries or different workplaces, and because of this have reached different conclusions about the extent of change in industrial relations. Some companies have become well known for their attempts to change employment relationships within their places of work (for example British Airways), and individuals who investigate people-management there may come up with different conclusions from students who have examined patterns of industrial relations in certain parts of the engineering industry or public sector. This point has been intimated by Terry (1986) in his review of shop steward organisation.

The third explanation is that different evaluations are due, at least in part, to different research methods which have been employed by investigators (see Morris and Wood, 1991). These authors have conducted case study work in some of the same organisations which were the subject of survey research by a different team, and they conclude that some of the divergence in results can be accounted for by the difference in research instruments and reliance in the survey on a single general question rather than an open-ended exploration of ideas in the interviews. They feel, quite rightly, that industrial relations specialists are able to exploit openings and pick up clues in semi structured interviews which would not have been uncovered by professional survey interviewers who were trying to code responses according to predetermined categories (1991: 280-281).

There is little doubt that each of these arguments provide an explanation about the divergent findings regarding the extent of change in British industrial relations during the 1980s. However, it may well be that the task of providing a universal description of any system of industrial relations is misguided, and that comparative texts downplay significant differences between workplaces in order to arrive at some nationally consistent picture. There are at least three sets of reasons why the task is misguided, especially in the context of the British system.

First of all, the backcloth or contextual factors provide no more than a potential or opportunity for change, of which employers may or may not choose to take advantage. It has been the case in Britain that, although there have been substantial legal changes, many 
employers have not chosen to take full advantage of these when dealing with trade unions (Towers, 1989: 171). Many employers have no desire to undermine trade unions, for a whole variety of reasons - for example, they may feel that unions represent a useful channel through which to deal with collective affairs - and even if they do have the desire to undermine or weaken trade unions, they may not have the ability to so do (Marchington and Parker, 1990: 25-26). The limited number of examples where employers have taken out injunctions against trade unions, or have chosen to dismiss their entire workforce during an industrial dispute shows the limited use of such legal rights in practice.

The second reason why the task is misguided is that the assumption of change implies that not only do we know how to describe British industrial relations in the early 1990s, but also where this stood in 1979. Neither of these is an easy task due to the quality of evidence available for either period, especially the latter. More seriously however, the idea of fundamental change under Thatcherism assumes that there have been adjustments from a system which was characterised by strong trade union organisation, large workplaces, formalised management techniques, and a history of industrial action. This may well have been a semi-accurate description of some parts of manufacturing industry as well as the public sector in 1979, but it had little meaning and relevance in the context of small businesses and employers in the private service sector. Just because the majority of research in industrial relations was conducted in manufacturing (and to a lesser extent in the public sector), this should not be taken as evidence that these workplaces were typical of all employment in the UK. This undue emphasis on the manufacturing paradigm has become even more problematic given the sectoral shifts in the economy as well as the fact that many employees now have experience of working only in small organisations or in the private service sector. Under this reasoning, therefore, we have to be very careful about attributing changes in the overall character of industrial relations to change in specific workplaces, when in fact the aggregate adjustments may be due to sectoral change.

Third, we need to consider the extremely decentralised nature of the British system of industrial relations. As Beaumont (1990: 35) indicates on the basis of a number of studies, the degree of centralisation in Britain is much lower than in many other countries; on average, Britain comes about three quarters down the list in terms of centralisation, and only a few other countries are about the same or more decentralised (the USA, Canada, Italy and France). This high degree of decentralisation means that a whole variety of patterns of industrial relations can be in existence given the relative lack of prominence of national institutions. This has always been true in Britain but has become even more prominent due to the deregulatory practices and individualist ideology of the Thatcher Government which have promoted a further fragmentation of the system. Taking collective bargaining as an example, what is apparent from all the surveys is that this is conducted increasingly on a single employer only basis, but within that bargaining may take place at corporate, divisional, establishment or even sectional level (Purcell, 1991: 41).

\section{Previous typologies of industrial relations}

As indicated in the introduction to this article, a more fruitful way forward is to deconstruct the idea of a unified national system and instead build up a series of ideal types. There have been a number of attempts to do this, both in the UK and in Australia over the last few years. Broadly, these take one of three different forms. First there are typologies 
which are based around management's approach to industrial relations of which the best known is Purcell and Sisson $(1983,1987)$. This has been adapted and modified by Marchington and Parker (1990) who have suggested that, whilst the idea of management style makes some sense, the dimensions on which the differentiation is based are in need of some refinement. However, both of these approaches have been criticised for combining procedural and substantive factors on the same dimension; for example the major difference between the consultative and the constitutional style has to do with attitudes, whereas other styles are differentiated by the existence and use of procedures (Marchington and Harrison, 1991). Other writers have also attempted to construct typologies of industrial relations strategy (Thurley and Wood, 1983) or management style (Thomason, 1984), but both of these come in for criticism on the grounds of their highly generalised nature or the deterministic links which are suggested between product markets and the management of people.

The second approach can be found in the work of Paul Edwards (1986) who, though explicitly rejecting the whole notion of typologies, nevertheless constructs his own patterns of industrial relations which are based upon an assessment of worker/employee approaches and organisation, as opposed to those which focus on management. This differentiates between workplaces on the basis of whether or not employees have a militant or an acquiescent orientation to their employer, the degree to which an individual or collectivist orientation exists, and the extent to which a collective orientation has been translated into a collective organisation (p.226).

Third, a number of authors have tried to construct typologies which are based on a combination of parties and factors. For example, Fox (1974) proposes six patterns of management - employee relations by applying (albeit rather loosely) the unitary - pluralistic distinction to both management and employee views. Prior to his work with Sisson, Purcell (1981) developed an alternative classification based upon the notion of high or low trust and high or low formalisation (that is, the interaction between the parties) in order to produce four ideal types, but he does not appear to make use of this in subsequent publications. Anthony (1977) uses two dimensions - the strength or weakness of employee organisation, and the dependence/independence of the employer on/from national procedures, and this provides for the possibility of up to ten patterns of industrial relations. Unfortunately, these are not developed in any detail in his book, nor does he ground them with reference to particular types of organisations. More recently, in Australia, Littler et al. (1989) have adapted Anthony's ideas to their own national context in order to produce five ideal types, and they have gone much further by providing examples and discussing the dynamics of typologies. An alternative Australian categorisation can be found in Callus et al. (1991) - labelled "workplace types" - and this is based on a combination of three sets of factors (the extent of employee organisation, the way management structures its relations with employees, and the presence or absence of collective bargaining) which also produces five ideal types. These are different from the Littler et al. categorisation, and there has been some debate about the relative merits of each approach, as well as the foundations on which each of these are based (see, for example, Zappala (1990), Littler et al., (1990), Kitay, forthcoming).

Each of these various attempts to construct typologies differs in the degree to which the categories and dimensions are described. Some (for example, Anthony) merely produce a set of ideal types with no attempt to justify why these dimensions should be used; nor do they provide examples of their usage. Others (for example Purcell, 1981) describe the dimensions in great detail and provide a lengthy analysis of the cases. But, what none of these do with any rigour is explain why they have opted for their chosen dimension; nor do they justify their use as opposed to any other available dimension. 
Following a review of the previous attempts at typologies, it seems appropriate to differentiate between workplaces on the basis of three dimensions in order to produce a number of patterns of industrial relations.

The first of these is management organisation, and this refers to the industrial relations and personnel structures, policies and procedures of employers, and the degree to which their approach to employees is formalised and/or takes into account new ideas and techniques. This can tend towards a higher level or lower level. Second, we can differentiate on the grounds of worker organisation. A workplace where employees are well organised would typically involve a high degree of shop steward contacts and networks, and an interest in the activities of the union being shown by its members. In some cases a union may be present but it may play a relatively minor role within the workplace. In yet others, there may be no union presence whatsoever. Again, we can differentiate between workplaces on the basis of high or low worker organisation. Third, we can focus on the interaction between the parties, and their attitudes to one another, and this takes in notions of 'trust' (Purcell, 1981). It can vary from the broadly positive to the broadly negative. In the case of the former, management would typically regard employees as an important and valued resource, whilst employees would see their employer in a more positive as opposed to a negative light. In the case of a negative interaction, the relationships would tend to be more strained, not only between trade unions and employers but also between individual managers and their staff.

In the next section, on the basis of differentiation, five different patterns of industrial relations are described, and this incorporates a number of developments which have taken place over the course of the last decade. The five patterns are outlined in Figure 1 below.

Before analysing these in more detail however, two further points need to be clarified. First, each of the dimensions differentiates between employers in a way which is reflective of tendencies rather than absolute differences. For example, when we talk about interactions between employers and employees being broadly positive, this is not to deny that employers regard employees as a cost as well as viewing them as a resource. Similarly, when the interaction is seen as broadly negative, this is not to say that there are not positive features of the relationship but that it tends towards a more negative and adversarial relationship. The

FIGURE 1 - PATTERNS OF INDUSTRIAL RELATIONS IN BRITAIN

\begin{tabular}{|c|c|c|c|c|}
\hline CHARACTERISTIC & $\begin{array}{l}\text { MANAGEMENT } \\
\text { ORGANISATION }\end{array}$ & $\begin{array}{l}\text { WORKER } \\
\text { ORGANISATION }\end{array}$ & INTERACTION & EXAMPLE \\
\hline $\begin{array}{l}\text { "NEW" INDUSTRIAL } \\
\text { RELATIONS }\end{array}$ & $\mathrm{HIGH}$ & HIGH & POSITIVE & CHEMICALS \\
\hline $\begin{array}{l}\text { "OLD" INDUSTRIAL } \\
\text { RELATIONS }\end{array}$ & HIGH & HIGH & NEGATTVE & $\begin{array}{l}\text { PUBLIC } \\
\text { SECTOR }\end{array}$ \\
\hline EMPLOYEE RELATIONS & HIGH & LOW & POSITTVE & $\begin{array}{l}\text { FOOD } \\
\text { RETAILING }\end{array}$ \\
\hline HUMAN RELATIONS & LOW & LOW & POSITIVE & $\begin{array}{l}\text { MARKETING } \\
\text { AGENCY }\end{array}$ \\
\hline DIRECT CONTROL & LOW & Low & NEGATIVE & SWEATSHOP \\
\hline
\end{tabular}


same kind of cautions need to apply when assessing the characteristics of management and worker organisation. Second, when focusing on the workplace there is a danger that the wider context in which industrial relations is conducted appears to be ignored. Just because there is not a separate category for "the state", for example, does not mean that its influence is unimportant. On the contrary, each of the other dimensions implicitly incorporates elements from outside the workplace. This is most apparent in relation to interaction between employer and employees, but both management and worker organisation are clearly influenced by the wider context - for example, in the development of formal disciplinary procedures, the extent of trade union recognition, or the degree of union consciousness amongst employees.

\section{Patterns of industrial relations in Britain}

a)

\section{"New" industrial relations}

This pattern of industrial relations is one which has been typical of many manufacturing companies in the private sector, especially those which underwent a significant transformation in their competitive environment in the late 1970 s and early 1980s. This is especially characteristic of industries such as chemicals and certain parts of the engineering industry which produce high quality goods. Companies in this area tend to compete in international markets, often manufacturing high quality products on a world wide basis. During the $1980 \mathrm{~s}$ the market has become more competitive and also more internationally focused. Often these establishments are part of larger multinational corporations.

Management in this environment has been well organised for a number of years, and personnel and industrial relations procedures are highly structured. There would tend to be a number of personnel specialists in the organisation, often at corporate and establishment level. These are also the kind of organisations where sophisticated selection techniques, performance related pay, appraisal, and extensive training have become apparent during the course of the 1980 s. Although they were always well organised in management terms, they have now become even further advanced and are very much at the forefront of new initiatives and new developments. It is also the kind of organisation where there may be a personnel or industrial relations presence on the board or top level management committees.

Just as management has been well organised, so too are workers. Shop steward organisation would be extensive and there would be networks of communication and committees between different trade unions at the workplace. They are now less likely to have full time shop stewards than was the case in the early 1980s, and some of these organisations will have reduced the number of representatives as well as the amount of time which they devote to union duties. There will still be a high level of union membership, but this is an area in which the interest in trade unions appears to be declining - perhaps in response to management's structured attempts at improving employee relations.

These are the organisations where relationships between management and employees have been improved over the course of the decade. Interactions are now more likely to be based on high trust between the parties, cooperation, and the attempt to establish integrative relations between management and employees. Depending upon the industry, some of these organisations would have experienced sizeable industrial relations problems - especially through industrial action - in the late 1970 s, but the cutbacks of the early 1980 s have led to a restructuring of relations between employers and trade unions. Typical new initiatives may 
include single table bargaining, singe unionism, and considerable developments in employee involvement - especially of a direct form. In addition, these are the organisations where teamworking is more likely to have emerged.

\section{b) "Old" industrial relations}

This pattern of industrial relations is now more typical amongst public sector organisations than it is within the private sector. The context over the 1980 s has been one where there have been government constraints on spending via the imposition of targets and limits on expenditure. In addition, this has often been associated with contracting - out of certain services. At the same time, there has been an expectation that these organisations should become more customer oriented, and there has been a big push towards greater care for consumers.

As with the previous pattern, management has traditionally been well structured, in the case of public service organisations for example, since the early 1970s. Procedures are extensive and industrial relations is highly formalised. Personnel specialists are evident throughout the organisation and there have been moves in recent years towards more sophisticated selection procedures, though perhaps not as advanced as in the previous pattern. Equal opportunities is likely to be an issue high on the agenda in these organisations. The whole flavour of these organisations is one of highly formalised management approaches to industrial relations.

In a similar vein, workers are also highly organised, and this has been the sector in which there has continued to be growth in the number of full-time shop stewards. Union membership has remained at a high level in the public sector, although there has been some fragmentation of unions especially at senior levels in local authorities. Compared with other sectors, members remain more interested in the activities of their unions, but this would also appear to be on the decline as employers engage in more attempts to involve and integrate employees.

This is the area in which relations between the parties have deteriorated most during the course of the last ten years. In the late 1970s, the public sector was renowned for the quality of relationships between employer and employee, and the notion that the state was "a model employer". During the 1980s the relationship has become increasingly strained, largely due to constraints on spending and also the centralised structure of the industrial relations procedures. It is the sector in which there has been the most serious and long-running strikes, and relations have been characterised by a lack of trust. This is reinforced by a constitutional/arms length relationship between the parties. Employee involvement can be observed in this sector but it is more likely to be formal and based upon collective institutions. Collective bargaining is still conducted at national level, at least in terms of setting the main structures and practices, although there is a move towards local bargaining especially over areas connected with flexibility, work organisation, and supplementary payments.

\section{c) Employee relations}

This pattern would be typical of much of the private services sector, and within that is probably most clearly seen within large food retailers. The context is one in which 
competition has increased between the major players during the 1980 s, but there has also been a significant concentration of ownership within these industries, and an increase in market share for the top few companies. Increasingly, goods are being sold on the basis of quality, as opposed to price, and as yet there has been little foreign intervention in this industry. Clearly, this varies between different parts of the sector, but - in food retailing for example - the vast majority of market share is still held by British owned organisations. Also, during the 1980 s, this was the sector which experienced continued market growth both in terms of overall market size and in terms of employment, although some parts of the sector (for example finance) began to suffer employment losses in 1990.

It is within this sector that management has become much more structured in terms of its approach towards industrial relations (often referred to as employee relations) over the last decade. Procedures are now much more extensive than they were a decade ago, and many more personnel specialists are employed, often at head office. Establishments in some parts of the sector are becoming much larger as well. Selection procedures for certain occupational groups (especially managers) have become more sophisticated, although high levels of labour turnover make this rather more problematic in certain areas (for example, sales floor and check out staff). Training has also developed over the course of the 1980s but this tends to be prescriptive and orientated towards strict conformance with best practice; this is especially apparent in the area of customer care.

Worker organisation is much less developed. The typical caricature of a private service sector organisation would be one in which there is no or very little union organisation. However, there are a number of companies where union membership has grown to quite high levels during the last decade; for example at two of the largest food retailers, union density is now of the order of $70 \%$ following recognition agreements in the latter part of the 1970 s. However, despite the overall level of unionisation, there is little development at the workplace and the unions find it difficult to recruit sufficient shop stewards to develop this more effectively. Often there are vacancies for shop stewards, and the people who actually hold these positions may be lacking in experience and length of service. These are the kind of organisations where union consciousness is low, and unions are no real impediment to employers.

Relationships between the parties have generally been much less adversarial than in the manufacturing or public sectors, and historically there was a large element of informality at establishment level. During the 1980 s, as we have already noted, management has become more structured, and in addition wages and conditions have improved over the course of the decade. The largest food retailers have now withdrawn from the National Employers' Association, and conduct their own bargaining as single employers. There are a number of attempts to develop employee involvement and communications, and there is also evidence of a growth in profit sharing and share ownership in this sector.

\section{d) Human relations}

This has been yet another major growth area in the economy, and it relates to small often single establishment - organisations which have become much more important during the course of the previous decade. Their position has been helped by the practice of larger firms subcontracting more activities to other employers, as well as the sectoral shifts in the British economy. As with the previous patterns, the context is one of increasing quality, and this is seen especially in organisations such as marketing agencies, firms of solicitors or 
accountants, and organisations which specialise in high quality engineering or other activities.

The management of industrial relations in this sector is still relatively unstructured and informal, and there are very few personnel specialists, even in the case of multi-establishment organisations. The aim is for long service and high quality employees who remain with the employer for quite a few years. Although for the most part selection will still be conducted on an informal basis, there is evidence that more sophisticated procedures are being used by these employers. In this sector, it is very unlikely that there will be any union organisation, partly because of the size of firms but also because of the kind of people who work for these organisations.

The relationships between the parties tend to be harmonious and cooperative, and employers are heavily reliant on ensuring that they retain good quality staff. This gives an incentive to achieve close working relationships and this can be seen through taskforces and teamworking, as well as in relatively open networks between managers and their staffs.

\section{e) Sweatshop/direct control}

The pattern of industrial relations seen in this sector is one which has hardly changed at all during the 1980s and is probably typified by Purcell and Sisson's category of traditional/ authoritarian management style. In these industries, there is likely to be intense competition, but usually on the basis of price rather than quality. Depending upon the sector, competition is mainly between UK companies, although in manufacturing there is now increasing pressure from overseas organisations (especially in the newly industrialising countries in the Pacific rim) which is putting yet more pressure on employers.

Neither management nor workers have much in the way of formal organisation. It would be very unlikely that the company - often family owned - would have any personnel specialists, and it may well be that one individual member of management has responsibility for overseeing the people aspects of the business. The approach adopted by management would be informal, but tough. Union membership and organisation would be highly unlikely in this pattern of industrial relations, and employers would work very hard to ensure that unions were kept out - often through fear tactics.

The relations between parties may have on occasion a veneer of benevolence or paternalism, especially during the good or buoyant times, but this would mask a tougher approach which underlies this. Low wages, long hours, and poor working conditions would be characteristic of this pattern of industrial relations, and employers may seek to pay at or below any legal requirements. Both parties would have a calculative attitude to work, and many of the people who are employed would be part-timers, students, or overseas workers who are employed on a temporary basis. During the 1980 s the approach adopted by these employers would have remained impervious to changes elsewhere, and these employers would be unaware of or highly dubious about the more sophisticated patterns which we have analysed above. 


\section{Conclusions}

The key point to emerge from this analysis is that it is very difficult to paint a single picture of British industrial relations. Rather, we can suggest that there have been several strands or patterns which have emerged and been sustained during the course of the 1980 s, and there are distinct differences between each of these. For example, there is so much difference between the first category outlined (New Industrial Relations) and the final (Sweatshop/Direct Control) that these could be on different planets let alone different parts of the same country. The key point is that it is difficult, especially in the context of the UK with its emphasis on deregulation and decentralisation, to paint an all-embracing picture of British industrial relations.

Although it is beyond the scope of this paper, we need clearly to move beyond the level of description outlined above, and try to pinpoint reasons why there may be differences in industrial relations between different workplaces. Previous work undertaken by the author (see Marchington and Parker, 1990, for example) has focused on the role of both product and labour markets and the way in which management interpret these in order to choose an appropriate style.

There are also a number of implications which emerge from this analysis. First of all, it leads one to question the value of comparative industrial relations texts which describe a country in a universal or all-embracing manner. The recent AWIRS attempt to derive "workplace types" shows that, even in the context of a more centralised economy than Britain, it is difficult to propose one style which would be representative of all workplaces. The second implication is that we need a review and critique of the different typologies of industrial relations, and this will be the subject of a future publication by Kitay/Marchington. Finally, we also need to reiterate the value of qualitative - as opposed to quantitative research approaches in order to tease out the intricacies and sensitivities of workplace industrial relations. Surveys are very valuable in order to provide a snapshot of industrial relations at any point in time, but we also need to explore the way in which detailed practices are worked out within individual establishments. Hopefully, although a fairly broad-brush approach has been adopted, the analysis presented here will provide a greater understanding of the diversity of industrial relations in Great Britain.

\section{References}

Anthony, P. (1977), The Conduct of Industrial Relations, London, IPM.

Batstone, E. (1984), Working Order, Oxford, Blackwell.

Beaumont, P./(1990), Change in Industrial Relations, London, Routledge.

Callus, R., Morehead, A., Cully, M. and Buchanan, J. (1991), Industrial Relations at Work, Canberra, AGPS.

Edwards, P. (1986), Conflict at Work, Oxford, Blackwell. 
Fox, A. (1974), Beyond Contract: Work, Power and Trust Relations, London, Faber.

Kitay, J. (1991), Analysing Workplace Industrial Relations: the Australian Workplace Industrial Relations Survey Typology, Journal of Industrial Relations, 33(4):547-63.

Littler, C., Quinlan, M. and Kitay, J. (1989), Australian Workplace Industrial Relations: Towards a Conceptual Framework, Journal of Industrial Relations, 31(4):500-25.

Littler, C., Quinlan, M. and Kitay, J. (1990), Australian Workplace Industrial Relations: A Rejoinder to Zappala, Journal of Industrial Relations, 32(4):582-87.

MacInnes, J. (1987), Thatcherism at Work, Milton Keynes, Open University Press.

Marchington, M. and Harrison, E. (1991), Customers, Competitors and Choice: Employee Relations in Food Retailing, Industrial Relations Journal, 22(4):272-85.

Marchington, M. and Kitay, J. (1991), A Review and Critique of Typologies in Workplace Industrial Relations, in preparation.

Marchington, M. and Parker, P. (1990), Changing Patterns of Employee Relations, Hemel Hempstead, Harvester Wheatsheaf.

Metcalf, D. (1989), Water Notes Dry Up: The Impact of the Donovan Reform Proposals and Thatcherism at Work on Labour Productivity in British Manufacturing Industry, British Journal of Industrial Relations, 27(1):1-31.

Millward, N. and Stevens, M. (1986), British Workplace Industrial Relations, 1980-1984, Aldershot, Gower.

Morris, T. and Wood, S. (1991), Testing the Survey Method: Continuity and Change in British Industrial Relations, Work Employment and Society, 5(2):259-82.

Pollert, A. (1988), Dismantling Flexibility, Capital and Class, 34:42-75.

Purcell, J. (1981), Good Industrial Relations: Theory and Practice, London, Macmillan.

Purcell, J. (1987), Mapping Management Styles in Employee Relations, Journal of Management Studies, 24(5):534-48.

Purcell, J. (1991), The Rediscovery of the Management Prerogative: The Management of Labour Relations, Oxford Review of Economic Policy, 7(1):33-43.

Purcell, J. and Sisson, K. (1983), Strategies and Practice in the Management of Industrial Relations, in Bain, G., Industrial Relations in Britain, Oxford, Blackwell, 95-120.

Sisson, K. (1986), Contemporary Developments in Employee Relations, Employee Relations, $8(6): 8-14$. 
Terry, M. (1986), How do we Know if Shop Stewards are Getting Weaker?, British Journal of Industrial Relations, 24(2):169-80.

Thomason, G. (1984), A Textbook of Industrial Relations Management, London, IPM.

Thurley, K. and Wood, S., (1983), Industrial Relations and Management Strategy, Cambridge, Cambridge University Press.

Towers, B. (1989), Running the Gauntlet: British Trade Unions under Thatcher, 1979-1980, Industrial and Labour Relations Review, 42(2):163-88.

Zappala, J. (1990), Australian Workplace Industrial Relations: Towards a Conceptual Framework - A Comment, Journal of Industrial Relations, 32(4):577-81. 